\title{
PREDIKSI GERAKAN TANAH MENGGUNAKAN SEISMIK REFRAKSI DAN PEMODELAN NUMERIK DENGAN METODE SIRT DAN GAUSS-SEIDEL
}

\author{
Prediction of Soil Movement Using Seismic Refraction and \\ Numerical Modeling Using Sirt and Gauss Seidel Methods
}

\author{
ZULKIFLI PULUNGAN dan ZULFAHMI \\ Puslitbang Teknologi Mineral dan Batubara \\ Jalan Jenderal Sudirman 623, Bandung 40211 \\ Telp. 022 6030483, Fax. 0226003373 \\ e-mail: zoel@tekmira.esdm.go.id
}

\begin{abstract}
ABSTRAK
Gerakan tanah merupakan salah satu jenis bencana alam yang sering terjadi di Indonesia, yang mengakibakan rusaknya bentang alam, hilangnya harta, bahkan korban jiwa. Penelitian ini bertujuan menganalisis karakteristik batuan atau tanah dan pengaruhnya terhadap potensi bencana gerakan tanah. Hasil penelitian ini dapat memprediksi pergerakan batuan menggunakan korelasi data seismik refraksi dan pemodelan numerik. Metode ini dipilih karena cukup akurat, relatif mudah dalam pelaksanaan pengukurannya serta mampu memprediksi kondisi lapisan pembentuk batuan secara cepat. Jumlah lapisan batuan yang berhasil dideteksi sebanyak 3 lapisan. Lapisan pertama diinterpretasikan sebagai lapisan tanah permukaan berupa lapukan lempung pasiran dengan ketebalan antara 1,24 - 3,18 m. Lapisan kedua adalah lapisan batulempung yang kedap dan berperan sebagai bidang luncur longsoran dengan ketebalan antara 2,57 - 7,50 m. Lapisan ketiga mempunyai kecepatan gelombang 1143 - 2190 meter/detik, diprediksi sebagai lapisan batupasiran. Hasil pengamatan pertama dan kedua hampir tidak terjadi perubahan kecepatan rambat gelombang, sehingga diprediksi pada lapisan ini kondisi batuan relatif stabil. Hasil pengamatan lapangan dan pemodelan pergerakan tanah pada lokasi I diperkirakan 0,6 $\mathrm{mm} /$ hari atau 21,9 cm/tahun, sehingga bila tidak dilakukan penanganan yang benar dikhawatirkan akan terjadi kelongsoran. Pada lokasi II, kondisinya relatif stabil, tidak terjadi perubahan bentang alam yang ekstrem dan tidak akan terjadi pergerakan tanah yang menyebabkan kerusakan fatal.
\end{abstract}

Kata kunci : gerakan tanah, seismik refraksi, pemodelan numerik.

\begin{abstract}
Soil movement is one of the natural disasters that frequently occur in Indonesia and resulted in catastrophic damage to the landscape, loss of property also cause casualties. This study aims to analyze the nature and characteristics of the rock or soil and their effects on the potential of soil movements. This research has been conducted to predict the movement of rocks/soil using correlation data of seismic refraction and numerical modeling. This method was chosen because of its accurate, relatively easy to be implemented and could predict the layers of soil/rock quickly. The layers of rock detected were 3 layers. The first layer is interpreted as a layer of top soil with a weather sandy clay with thickness variations between 1,24-3,18 m. The second layer is claystone which is impermeable and acts as an sliding plane with a thickness variation between 2,57 $7,50 \mathrm{~m}$. While the third layer has a sesimic of 0,6 velocity wave $1143-2190 \mathrm{~m} / \mathrm{s}$ which is predicted as sandstone layer. At the second study site, the first and second observations show that there is almost no changes in seismic wave velocity so it can be predicted that the condition of the rock layer is relatively stable, although a very small deceleration was found at several points. Based on the results of field observations and modeling, the soil movement at location one is expected to be $0.6 \mathrm{~mm} /$ day or $21,9 \mathrm{~cm} /$ year, so it needs a
\end{abstract}


proper treatment to avoid failure again. The conditions of the second location is relatively stable and by assuming no change in the extreme landscape around the site, it can be concluded that there will be no soil movement which brings fatal damage.

Keywords: soil movement, seismic refraction, numerical modelling.

\section{PENDAHULUAN}

Meningkatnya intensitas hujan hampir di seluruh pelosok Indonesia menyebabkan sering terjadi bencana longsor akibat pergerakan tanah yang tak mampu menahan massa yang jenuh air. Potensi kelongsoran menduduki $28 \%$ kasus bencana yang menimpa wilayah Indonesia. Pusat Vulk anologi dan Mitigasi Bencana Geologi (PVMBG) mencatat lebih dari 124 kejadian gerakan tanah di Indonesia selama tahun 2013.

Besarnya jumlah kejadian gerakan tanah tersebut tidak terlepas dari kondisi lapisan batuan dan bentuk morfologi di sebagian wilayah Indonesia yang cenderung mempunyai kontur yang curam. Di samping itu, penggunaan lahan, struktur geologi, curah hujan dan gempa turut mendukung terjadinya pergerakan (Kusumosubroto, 2013). Menurut Karnawati (2005), terjadinya pergerakan batuan atau tanah disebabkan oleh aktivitas manusia yang merubah bentang alam sehingga terjadi ketidak stabilan di daerah tersebut, seperti kegiatan penambangan, pertanian, perumahan dan pembuatan jalan. Berbagai tipe pergerakan batuan, seperti runtuh (fall), roboh (topple), meluncur (slide), mengembang (spread) dan hanyut (flow) dapat terjadi tergantung pada sudut kemiringan lereng dan jenis materialnya (Wieczorek dan Snyder, 2009).

Banyak metode yang digunakan untuk mengetahui secara dini proses pergerakan batuan tersebut, misalnya dengan menggunakan prediksi spasial menggunakan regresi logistik dan receiver operating characteristic (Gorsevski dkk., 2006), instrumentasi elektronik (Dennis dkk., 2006; Zulfahmi, dkk, 2009), menggunakan peralatan survey topografi (Lateha dkk., 2010), remote sensing (Tofani dkk., 2013), permodelan numerik dan seismik (Narwold and Owen, 2003; Henryk dkk., 2003). Berbagai macam metode tersebut mempunyai kelebihan dan kekurangan tergantung pada kondisi lokasi yang dijadikan target pengamatan.
Pada penelitian ini dilakukan prediksi pergerakan batuan menggunakan korelasi data seismik refraksi dan pemodelan numerik. Metode ini dipilih karena cukup akurat, relatif mudah dalam pelaksanaan pengukurannya serta mampu memprediksi kondisi lapisan pembentuk batuan secara cepat. Kegiatan penelitian dilakukan di salah satu areal rawan longsor di Sawah Lunto, Sumatera Barat. Pengukuran dilakukan dengan 5 lintasan tegak lurus lereng dan 5 lintasan sejajar lereng atau 10 kali pengukuran pada dua lokasi yang berbeda.

Terjadinya retakan-retakan di sepanjang lintasan di sekitar lokasi penelitian merupakan salah satu indikasi telah terjadinya kerusakan struktur bawah permukan. Menurut Sato (2000), perubahan struktur tersebut akan memunculkan kerusakan yang lebih parah akibat adanya faktor eksternal dengan terbentuknya retakanretakan baru atau melebarnya retakan awal yang sudah ada. Untuk membuktikan terjadinya perubahan struktur bawah permukaan tersebut, telah dilakukan dua kali pengukuran dengan selang waktu tertentu pada lokasi yang sama. Hipotesis dari penelitian ini adalah terdapat hubungan antara kerusakan struktur dan perubahan kecepatan rambat gelombang seismik pada batuan dari waktu ke waktu. Adapun tujuan dari penelitian ini adalah untuk memprediksi pergerakan tanah secara dini berdasarkan perbedaan kecepatan rambat gelombang pada selang waktu tertentu di tempat yang sama.

\section{METODE}

Untuk mengevaluasi perkembangan penelitian pergerakan tanah sebelumnya, telah dilakukan studi literatur. Selanjutnya dari studi ini dibuat simpulan sementara dalam bentuk hipotesis sebagai acuan dalam penelitian yang dilakukan. Data sekunder berupa struktur geologi, parameter geoteknik dan kondisi struktur batuan setempat sebagai pelengkap data dalam mengevaluasi kondisi lokasi penelitian. Selanjutnya dilakukan pengambilan data seismik di 
daerah yang diteliti sebanyak masing-masing 10 kali dengan selang waktu tertentu pada dua lokasi yang berbeda. Kemudian terhadap data seismik yang diperoleh, dilakukan pengolahan menggunakan software WinSism dengan metode intercept time dan generalized reciprocal method (GRM). Metode ini fungsinya untuk mendapatkan nilai kecepatan rambat gelombang dan memprediksi kedalaman masingmasing lapisan batuan. Selanjutnya dengan menggunakan model perhitungan SIRT (simultaneous iterative reconstruction technique) dan Gauss-Seidel, dilakukan pengolahan data tomografi. Dari pengolahan ini dapat diketahui perubahan struktur masing-masing lapisan melalui perubahan kecepatan rambat gelombang. Data tersebut kemudian divisualisasikan dalam bentuk grafik dan dibuat persamaan garis untuk mengetahui besaran pergerakannya.

\section{Analisis Stabilitas Lereng}

Umumnya pergerakan tanah terjadi pada daerah yang mempunyai perbedaan kontur yang ekstrim seperti di lereng gunung, perbukitan atau areal penambangan. Gangguan terhadap kestabilan lereng bisa menyebabkan terjadinya pergerakan tanah atau kelongsoran yang akan berakibat fatal terhadap keselamatan, kerusakan lingkungan serta harta benda. Oleh karena itu, analisis kestabilan lereng sangat diperlukan dalam mencegah terjadinya gangguan akibat bahaya pergerakan tanah tersebut. Persoalan kestabilan lereng tergantung pada banyak faktor, baik eksternal maupun internal seperti berat massa batuan, karakteristik batuan, kejenuhan air tanah dan tekanan yang ditimbulkannya memiliki dampak pada hilangnya stabilitas lereng. Dalam keadaan seperti itu, prediksi dari setiap gerakan lereng harus melibatkan analisis kekuatan yang memengaruhi kekuatan massa batuan (Henryk dkk., 2003). Prediksi terhadap potensi kelongsoran lereng seringkali sangat sulit dilakukan, beberapa prosedur yang sering digunakan yaitu dengan kombinasi antara penyelidikan lapangan dengan permodelan (Zulfahmi, dkk., 2009). Teknik deteksi dini kondisi lereng yang diperkirakan rawan longsor dapat pula dilakukan secara langsung dengan melakukan pengukuran lapangan menggunakan instrumentasi misalnya dengan seismik refraksi. Sedangkan dengan cara tak langsung menggunakan permodelan numerik dengan mempertimbangkan data geometri lereng, ka- rakteristik massa batuan, kondisi heterogenitas dan diskontinuitas serta gaya luar, sehing-ga dapat disimulasikan kondisi lereng dengan melakukan perubahan terhadap parameterparameter tersebut. Namun demikian penggunaan pemodelan numerik bukanlah proses yang mudah. Banyak faktor yang dipertimbangkan, terutama dari aspek akurasi data yang menjadi parameter penentu. Interpretasi seismik juga sebaiknya diverifikasi oleh beberapa metode lain, seperti dengan lobang bor atau pembuatan paritan. Pemodelan numerik memungkinkan untuk menentukan faktor keselamatan dan menunjukkan kondisi-kondisi yang memiliki potensi longsor. Sedangkan survei seismik dapat digunakan sebagai konfirmasi lokalisasi areal yang akan mengalami kondisi yang tak stabil. Analisis terhadap kestabilan lereng ini akan dapat membantu mencegah, meminimalisir atau mengatasi terjadinya bencana longsor akibat pergerakan tanah atau batuan. Untuk menentukan kondisi kestabilan dan tingkat kerawanan suatu lereng dapat dilakukan beberapa hal seperti: memperkirakan bentuk keruntuhan kritis yang mungkin terjadi; menganalisis penyebab terjadinya longsor; mempelajari pengaruh gaya-gaya luar pada lereng; mendesain lereng galian atau timbunan yang optimal dan memenuhi kriteri keamanan dengan biaya yang ekonomis; memperkirakan kestabilan lereng; dan menentukan metode penguatan atau perbaikan lereng yang sesuai.

\section{Perkiraan Sifat dan Perilaku Tanah/Batuan}

Beberapa sifat batuan yang penting untuk diketahui dalam memperkirakan kekuatan batuan adalah poisson ratio $(\mathrm{Y})$, modulus young $(\mathrm{E})$, Bulk Modulus (K), Rigidity $(\mathrm{G})$ dan konstanta Lame $(\lambda$ dan $\mu$ ). Parameter ini dapat diketahui dengan memberikan beban dinamik ke dalam lapisan kulit bumi yang salah satunya menggunakan seismik refraksi. Li, dkk., (2009); Ohta dan Aydan (2009); Aydan dkk., (2009) dan Ferrero dkk., (2010) telah mengembangkan beberapa konsep perhitungan dinamik dan sepakat untuk menyatakan bahwa:

a). Poisson ratio ( $\mathrm{Y}$ ) adalah perbandingan regangan transversal (transverse strain) dengan regangan longitudinal (longitudinal strain).

b) Modulus young (E) merupakan perbandingan antara tegangan dan regangan.

c) Bulk Modulus (K) merupakan perbandingan tegangan dan perubahan volume material. 
d) Kebalikan dari persamaan ini (1/K) menyatakan kompressibilitas material. Rigidity (G) atau modulus geser (shear modulus) merupakan perbandingan tegangan geser (shearing stress) dengan regangan geser (shearing strain).

e) Sedangkan konstanta Lame $(\lambda$ dan $\mu)$ merupakan tetapan yang diturunkan dari besaran yang telah disebutkan sebelumnya.

Sementara itu secara empirik dengan menggunakan klasifikasi massa batuan, parameterparameter yang penting untuk menentukan kekuatan massa batuan dapat menggunakan modulus deformasi (Em), Mohr-Coulomb, gesekan (Ø) dan kohesi (c). Modulus deformasi massa batuan dapat diturunkan dengan menggunakan sistem klasifikasi umum seperti Q, Rock Mass Rating (RMR), Geological Strength Index (GSI), dan lain-lain. Menurut Hoek dan Brown (1997) dan Hoek dkk, (2002), data yang dibutuhkan untuk memperkirakan modulus deformasi (Em) adalah kuat tekan batuan intak $\left(\sigma_{\mathrm{ci}}\right)$, rating GSI atau RMR dan konstanta Hoek-Brown (mi).

\section{Pengukuran Dinamik dengan Seismik Refraksi}

Teknik penyelidikan dan interpretasi seismik refraksi telah banyak dikembangkan oleh para ahli, seperti Hagiwara, Matsuda dan Hawkins (lyer dan Hirahara, 1993; Watanabe dan Sassa, 1996). Mereka mempunyai prinsip yang sama dalam mengembangkan teknik pengukuran dengan mempertimbangkan beberapa hal sebagai berikut:

- Kecepatan gelombang selalu diasumsikan akan bertambah besar seiring dengan bertambahnya kedalaman $\left(\mathrm{V}_{1}<\mathrm{V}_{2}<\mathrm{V}_{3}\right)$;

- Kondisi lapisan batuan di bawah permukaan terbentuk dari beberapa lapisan batuan dengan kecepatan gelombang yang berbeda.

- Panjang gelombang seismik selalu lebih kecil dibandingkan dengan ketebalan lapisan batuan yang akan diselidiki.

- Jarak antara sumber getar (shoot point) dengan geophone terjauh selalu lebih besar dibandingkan dengan ketebalan lapisan.

- Ketelitian penafsiran tentang bentuk permukaan bidang batas antara lapisan batuan di bawah permukaan tergantung kepada jarak spasi antara geophone yang ditempatkan di permukaan.

- Penjalaran gelombang seismik pada bidang batas lapisan menggunakan gelombang yang lebih besar di lapisan bagian bawahnya.

- Untuk ketelitian hasil pengukuran, jarak horizontal dan waktu harus diukur secara teliti.

Prinsip penyelidikan seismik refraksi dapat dijelaskan melalui Gambar 1, yang menunjukkan kondisi dua lapisan sederhana dengan kecepatan gelombang berbeda $\left(V_{2}>V_{1}\right)$. Diasumsikan, sumber getar berada pada titik sumber (source) dan waktu datang gelombang ditangkap oleh Geophone jarak X.

Melihat kenyataan tersebut di atas, cukup sulit untuk merumuskan dan mengevaluasi kondisi perlapisan di bawah permukaan, namun bila sudah diketahui masing-masing gelombang yang bekerja dan memilahnya, maka kondisi dan kedalaman perlapisan dapat dengan mudah diketahui. Persamaan perambatan gelombang bias ditunjukkan oleh garis lurus dengan slope $1 / V_{2}$. Pada Gambar 2 dapat dilihat bahwa gelombang langsung akan tiba lebih dahulu dari pada gelombang bias. Dari perbedaan penerimaan ini, maka dapat ditemukan pertemuan antara gelombang langsung dan gelombang refraksi. Jarak antara sumber getar dengan pertemuan kedua gelombang ini disebut crossover distance (X cross). Demikian pula dengan gelombang refleksi, gelombang langsung selalu datang lebih cepat dibandingkan dengan gelombang refleksi. Gelombang yang paling cepat adalah gelombang refraksi, disusul gelombang refleksi, kemudian gelombang udara dan terakhir gelombang permukaan.

Gelombang langsung (direct wave), waktu penjalarannya dapat dihitung berdasarkan persamaan (lyer dan Hirahara, 1993):

$t_{\text {direct }}=\frac{X}{V 1}$

Untuk gelombang bias (refraction wave), waktu penjalarannya dapat dihitung dengan menggunakan persamaan (lyer dan Hirahara, 1993):

$t_{r e f r}=\frac{X}{V 2}+\frac{2 Z\left(V 2^{2}-V 1^{2}\right)^{\frac{1}{2}}}{V 1 V 2}$ 


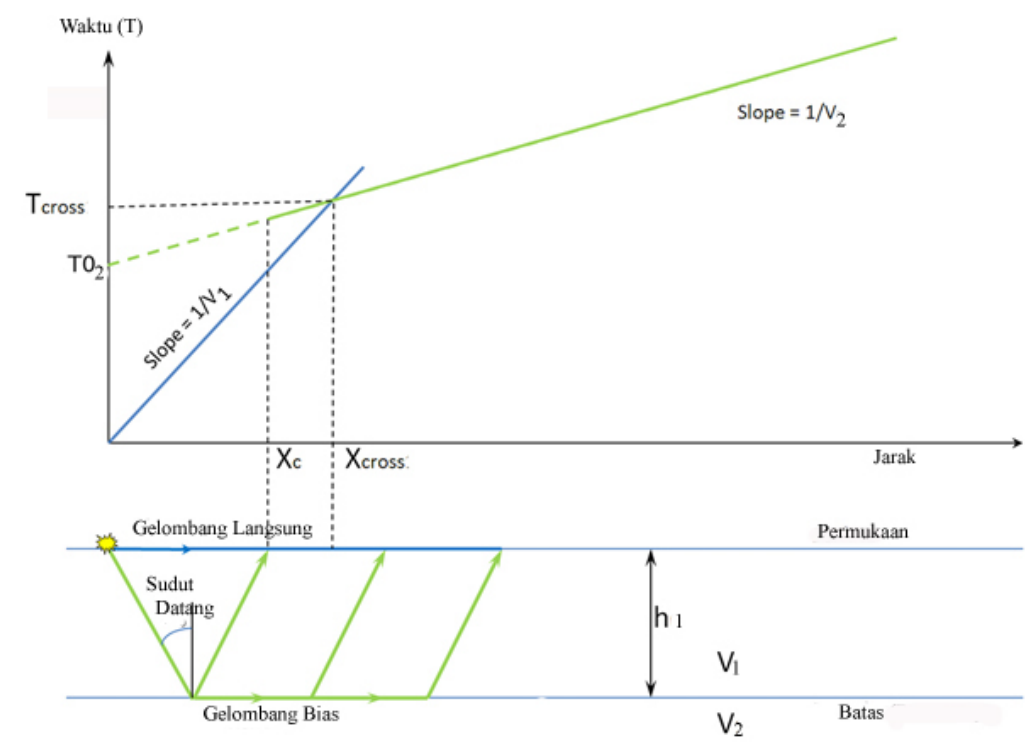

Gambar 1. Prinsip penyelidikan seismik refraksi

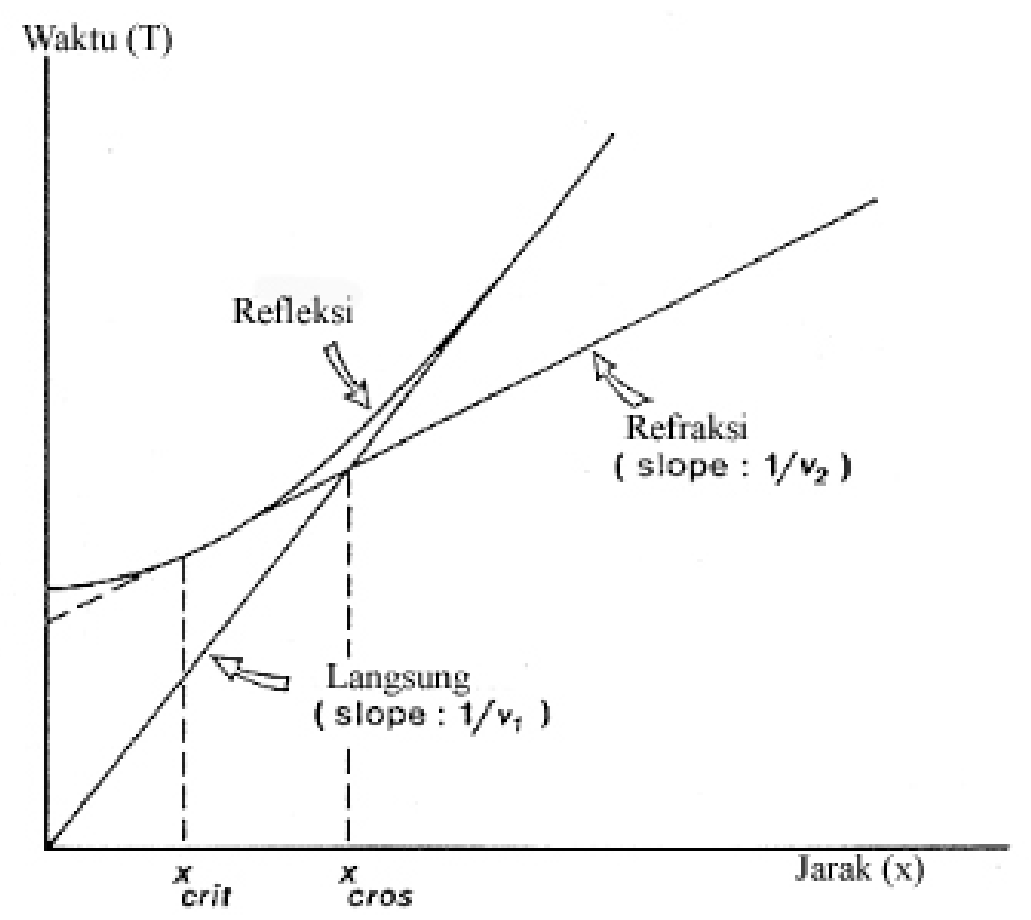

Gambar 2. Gelombang refleksi, refraksi dan langsung

Sedangkan untuk gelombang pantul (reflected wave), waktu penjalarannya dapat dihitung dengan menggunakan persamaan (lyer dan Hirahara, 1993):

$t_{\text {refl }}=\frac{\left(X^{2}+4 Z^{2}\right)^{\frac{1}{2}}}{V 1}$
Berdasarkan ketiga persamaan tersebut di atas, maka dapat dilakukan plotting dengan menggunakan prediksi penjalaran waktu tempuh gelombang dan jarak. Hasil plotting ini disebut dengan kurva waktu jarak (time distance curve). Untuk gelombang langsung (direct wave) dapat ditunjukkan oleh suatu garis lurus dengan slope $1 / \mathrm{N}_{1}$ yang dimulai dari pusat kurva waktu - jarak. 


\section{HASIL DAN PEMBAHASAN}

\section{Lokasi Pengukuran Lapangan}

Pengambilan data lapangan dilakukan dua tahap, yaitu tahap pertama dilakukan pengukuran awal untuk melihat kondisi pada saat dimulainya pengukuran, kemudian tahap kedua dilakukan dua bulan setelah pengukuran pertama dilakukan. Perbedaan kondisi antara penyelidikan pertama dan kedua dijadikan dasar dalam melakukan perhitungan pemodelan menggunakan metode SIRT dan GaussSiedel. Survey awal dilakukan pada areal yang diperkirakan ekstrem dan telah terjadi kelongsoran, yaitu di areal bekas penambangan liar dan telah terjadi perubahan fungsi lahan dari hutan ke penambangan dan perumahan. Gambar 3 menunjukkan areal yang dijadikan lokasi pengukuran seismik dan pada Gambar 4 menunjukkan terjadinya pergerakan tanah di bawah lereng yang menyebabkan rusaknya salah satu rumah penduduk. Selain itu dilakukan juga pengukuran areal yang tak ekstrem dengan kondisi lereng yang datar, seperti terlihat pada Gambar 5.

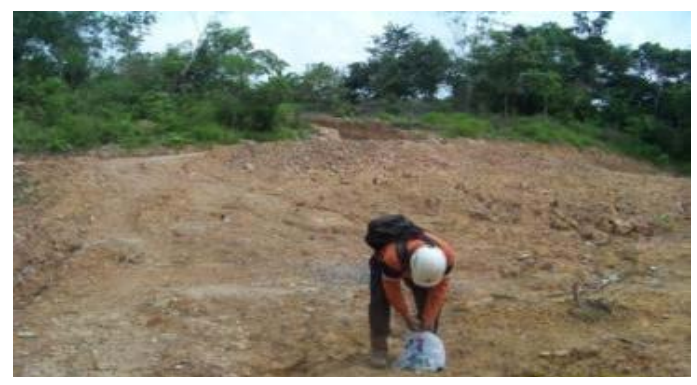

Gambar 3. Lokasi pertama penelitian (bagian puncak lereng)

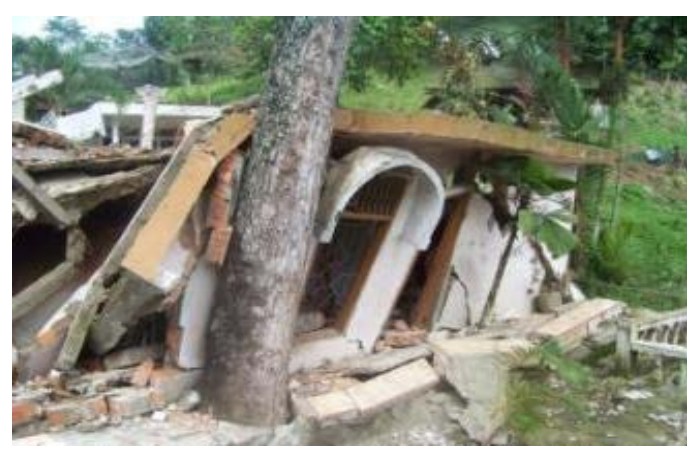

Gambar 4. Lokasi bagian bawah penelitian pertama

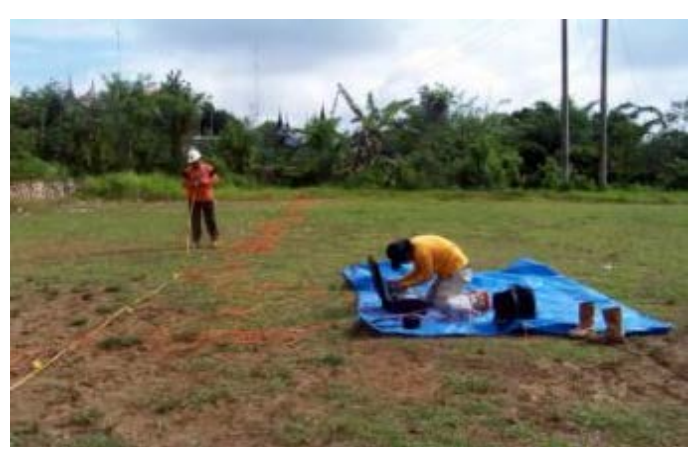

Gambar 5. Lokasi penelitian kedua

\section{Evaluasi Hasil Pengukuran Seismik}

Pada umumnya pengolahan data seismik dilakukan dengan diawali proses penyaringan (filtering) data untuk menghilangkan atau mengurangi gangguan (noise), sehingga dapat diketahui sinyal yang berasal dari gelombang bias (refraksi), pantul (refleksi), ataupun gelombang langsung. Kemudian dilanjutkan dengan melakukan penentuan waktu tiba pertama (first arrival time picking) untuk setiap titik tembak (shot point) yang berbeda. Dari hasil penentuan waktu tiba pertama tersebut kemudian diplot pada pada kurva atau grafik hubungan jarak dengan waktu tiba dan dimasukkan juga data posisi geophone. Dari grafik yang dihasilkan tersebut dilakukan analisis data waktu tempuh (travel time) untuk mendapatkan model lapisan bawah permukaan dua dimensi. Dari hasil tahapan tersebut akan didapatkan nilai koordinat geophone, nilai kecepatan gelombang untuk masing-masing lapisan dan tebal tiap lapisan setiap receiver atau geophone. Selanjutnya setelah 60 hari ( 2 bulan kemudian), dilakukan pengukuran ulang dengan metode seismik refraksi yang sama pada lokasi yang sama. Tabel 1 dan 2 adalah data hasil pengolahan dari pengukuran awal dan akhir di lokasi penelitian dengan selang waktu 60 hari pada dua lokasi berbeda.

Sedangkan Tabel 2 adalah data hasil pengolahan pengukuran awal dan akhir pada lokasi kedua dengan posisi pengukuran sejajar.

Dari Tabel 1 dan 2, berdasarkan karakteristik kecepatan rambat gelombang seismik pada beberapa material seperti pada Tabel 3, maka dapat ditafsirkan jenis lapisan batuan yang mendukung lereng tersebut. 
Berdasarkan Tabel 3 hasil perhitungan dan pengamatan di lapangan dapat ditafsirkan jenis lapisan batuan pada lokasi penelitian :

Lokasi I.

- Lapisan pertama dengan ketebalan bervariasi antara 0.74 - $3.91 \mathrm{~m}$ dan kecepatan gelombang 400 - $712 \mathrm{~m} / \mathrm{s}$ diinterpretasikan sebagai lapisan tanah bagian atas berupa tanah lapukan lempung pasiran (sandy clay).

- Lapisan kedua dengan ketebalan bervariasi antara 1.9 - $9.0 \mathrm{~m}$ dan kecepatan gelombang 870 - $2223 \mathrm{~m} / \mathrm{s}$ diinterpretasikan sebagai lapisan batulempung (claystone)

- Lapisan ketiga dengan kecepatan gelombang 2025 - 4705 m/s diinterpretasikan sebagai lapisan pasir (sandstone).

Lokasi II

- Lapisan pertama dengan ketebalan bervariasi antara 0.9 - $1.5 \mathrm{~m}$ dan kecepatan gelombang 173 - $248 \mathrm{~m} / \mathrm{s}$ diinterpretasikan sebagai lapisan tanah bagian atas.

- Lapisan kedua dengan ketebalan bervariasi antara 0.89 - 3.30 dan kecepatan gelombang 2051 - 2580 m/s diinterpretasikan sebagai lapisan batu lempung (claystone).

- Lapisan ketiga dengan kecepatan gelombang 1143 - 2580 m/s diinterpretasikan sebagai lapisan pasir (sandstone).

Berdasarkan data lobang bor dari Koning (1985), menunjukkan bahwa pada formasi Sawahlunto dan Ombilin terdapat lapisan batuan yang umumnya terdiri dari Sandstone, siltstone, claystone dan batubara. Melihat dari interpretasi ini, daerah telitian berada pada dua lapisan batuan yang rentan akan pergerakan, karena lapisan batulempung berada di atas lapisan batupasir yang akan bergerak bila ada perubahan kondisi lapisan batuan seperti pengaruh perubahan air tanah atau infiltrasi air permukaan.

Tabel 1. Hasil analisis data seismik lokasi pertama (sejajar lereng)

\begin{tabular}{|c|c|c|c|c|c|c|c|c|c|c|c|c|c|}
\hline \multirow[b]{2}{*}{ Geo } & \multirow[b]{2}{*}{$\mathrm{x}$} & \multirow[b]{2}{*}{ y } & \multirow[b]{2}{*}{ z } & \multicolumn{5}{|c|}{ Pengukuran awal } & \multicolumn{5}{|c|}{ Pengukuran akhir } \\
\hline & & & & $\begin{array}{l}\mathrm{V} 1 \\
(\mathrm{~m} / \mathrm{s})\end{array}$ & $\begin{array}{l}\text { E1 } \\
(\mathrm{m})\end{array}$ & $\begin{array}{c}\mathrm{V} 2 \\
(\mathrm{~m} / \mathrm{s})\end{array}$ & $\begin{array}{c}\text { E2 } \\
(\mathrm{m})\end{array}$ & $\begin{array}{l}\text { V3 } \\
(\mathrm{m} / \mathrm{s})\end{array}$ & $\begin{array}{l}\mathrm{V} 1 \\
(\mathrm{~m} / \mathrm{s})\end{array}$ & $\begin{array}{l}\text { E1 } \\
(\mathrm{m})\end{array}$ & $\begin{array}{c}\mathrm{V} 2 \\
(\mathrm{~m} / \mathrm{s})\end{array}$ & $\begin{array}{c}\text { E2 } \\
(\mathrm{m})\end{array}$ & $\begin{array}{c}\text { V3 } \\
(\mathrm{m} / \mathrm{s})\end{array}$ \\
\hline 1 & 464.5 & 447.3 & 420.4 & 420 & 3.1638 & 1321 & 0.5846 & 2575 & 407 & 3.1802 & 1421 & 3.6010 & 2401 \\
\hline 2 & 462.0 & 444.1 & 421.2 & 440 & 2.9737 & 1311 & 2.5728 & 2574 & 451 & 3.0002 & 1335 & 3.6000 & 2451 \\
\hline 3 & 460.1 & 440.5 & 421.7 & 455 & 2.8155 & 1286 & 4.6794 & 2574 & 486 & 2.8285 & 1671 & 4.1000 & 2431 \\
\hline 4 & 458.1 & 436.9 & 422.2 & 485 & 2.6476 & 1280 & 4.9874 & 2536 & 526 & 2.6512 & 1655 & 4.9000 & 2551 \\
\hline 5 & 456.1 & 433.3 & 422.8 & 515 & 2.4741 & 1260 & 5.8774 & 2536 & 521 & 2.4801 & 1501 & 5.8000 & 2551 \\
\hline 6 & 454.2 & 429.8 & 423.6 & 530 & 2.2731 & 1244 & 6.3842 & 2531 & 585 & 2.2902 & 1545 & 6.6010 & 2505 \\
\hline 7 & 452.2 & 426.2 & 424.8 & 573 & 2.1158 & 1215 & 6.8660 & 2533 & 602 & 2.1287 & 1545 & 6.9050 & 2399 \\
\hline 8 & 50.2 & 422.6 & 425.6 & 600 & 1.9320 & 1201 & 8.2670 & 2533 & 602 & 1.9505 & 1490 & 7.3020 & 2205 \\
\hline 9 & 448.3 & 419.0 & 425.4 & 650 & 1.7607 & 1185 & 7.4785 & 2374 & 651 & 1.7782 & 1420 & 7.5010 & 2100 \\
\hline 10 & 446.3 & 415.4 & 425.9 & 645 & 1.5764 & 1155 & 6.7606 & 2411 & 685 & 1.5913 & 1351 & 6.8050 & 2051 \\
\hline 11 & 444.0 & 412.0 & 426.7 & 670 & 1.4224 & 1153 & 6.8682 & 2451 & 708 & 1.4210 & 1270 & 6.8850 & 2020 \\
\hline 12 & 441.8 & 408.6 & 426.3 & 700 & 1.2455 & 1134 & 5.9017 & 2451 & 722 & 1.2580 & 1270 & 6.6000 & 2350 \\
\hline 13 & 439.5 & 405.2 & 426.5 & 710 & 1.2712 & 1126 & 5.9861 & 2457 & 728 & 1.2601 & 1151 & 6.0000 & 2350 \\
\hline 14 & 437.2 & 401.8 & 426.5 & 660 & 1.2812 & 1148 & 5.9869 & 2457 & 755 & 1.2491 & 1150 & 6.1000 & 2480 \\
\hline 15 & 435.0 & 398.4 & 426.6 & 645 & 1.2767 & 1168 & 5.9868 & 2421 & 801 & 1.3505 & 1120 & 6.1000 & 2490 \\
\hline 16 & 432.7 & 395.0 & 427.1 & 610 & 1.3756 & 1184 & 6.0769 & 2375 & 821 & 1.9890 & 1115 & 6.1000 & 2501 \\
\hline 17 & 430.4 & 391.6 & 427.8 & 600 & 1.4249 & 1202 & 5.9804 & 2485 & 835 & 1.4430 & 1110 & 6.0000 & 2501 \\
\hline 18 & 428.2 & 388.2 & 428.8 & 587 & 1.5112 & 1220 & 6.1651 & 2531 & 901 & 1.4902 & 1110 & 6.2000 & 2405 \\
\hline 19 & 425.9 & 384.7 & 429.8 & 547 & 1.5553 & 1243 & 6.0673 & 2531 & 941 & 1.5285 & 1102 & 6.1000 & 2401 \\
\hline 20 & 423.6 & 381.3 & 430.9 & 533 & 1.5657 & 1254 & 5.6287 & 2537 & 1001 & 1.5790 & 1102 & 5.4000 & 2355 \\
\hline 21 & 421.4 & 377.9 & 431.7 & 481 & 1.5988 & 1275 & 5.4618 & 2534 & 1025 & 1.6302 & 1131 & 5.5000 & 2355 \\
\hline 22 & 419.1 & 374.6 & 432.9 & 454 & 1.6558 & 1288 & 4.6931 & 2544 & 985 & 1.6702 & 1138 & 4.7000 & 2365 \\
\hline 23 & 416.7 & 371.2 & 433.7 & 431 & 1.7056 & 1311 & 4.7968 & 2544 & 981 & 1.7200 & 1138 & 4.8000 & 2401 \\
\hline 24 & 414.4 & 367.8 & 434.6 & 408 & 1.7888 & 1331 & 4.7978 & 2575 & 981 & 1.7700 & 1141 & 4.8000 & 2335 \\
\hline
\end{tabular}


Tabel 2. Hasil analisis data seismik lokasi kedua (sejajar lereng)

\begin{tabular}{|c|c|c|c|c|c|c|c|c|c|c|c|c|c|}
\hline \multirow[b]{2}{*}{ Geo } & \multirow[b]{2}{*}{$x$} & \multirow[b]{2}{*}{ y } & & \multicolumn{5}{|c|}{ Pengukuran Awal } & \multicolumn{5}{|c|}{ Pengukuran Akhir } \\
\hline & & & & $\begin{array}{l}\mathrm{V} 1 \\
(\mathrm{~m} / \mathrm{s})\end{array}$ & $\begin{array}{l}\text { E1 } \\
\text { (m) }\end{array}$ & $\begin{array}{c}\mathrm{V} 2 \\
(\mathrm{~m} / \mathrm{s})\end{array}$ & $\begin{array}{c}\text { E2 } \\
\text { (m) }\end{array}$ & $\begin{array}{c}\text { V3 } \\
(\mathrm{m} / \mathrm{s})\end{array}$ & $\begin{array}{l}\mathrm{V} 1 \\
(\mathrm{~m} / \mathrm{s})\end{array}$ & $\begin{array}{l}\text { E1 } \\
\text { (m) }\end{array}$ & $\begin{array}{c}\mathrm{V} 2 \\
(\mathrm{~m} / \mathrm{s})\end{array}$ & $\begin{array}{c}\text { E2 } \\
\text { (m) }\end{array}$ & $\begin{array}{l}\text { V3 } \\
(\mathrm{m} / \mathrm{s})\end{array}$ \\
\hline 1 & 1.00 & 50.00 & 432 & 302 & 0.6966 & 540 & 3.2960 & 888 & 252 & 0.7010 & 867 & 3.3006 & 844 \\
\hline 2 & & & & 302 & & & & & & & & 9806 & 344 \\
\hline 3 & & & & 302 & 6575 & 607 & 1962 & 888 & 273 & .6610 & 875 & 2006 & 885 \\
\hline 4 & & & & 302 & 6374 & 640 & 0980 & 1066 & 283 & & 879 & 1006 & 1095 \\
\hline 5 & & & & 302 & & 674 & 2.0987 & 1311 & 294 & .6210 & 883 & .1006 & 1449 \\
\hline 6 & & & & 30 & & 008 & & & & & & 3006 & 020 \\
\hline 7 & & & & 30 & & & & & & & & & 081 \\
\hline 8 & & & & 30 & & 77 & & & & & & 06 & 1644 \\
\hline 9 & & & & 303 & & 809 & 7970 & & & & 899 & .8006 & 2049 \\
\hline 10 & & & & 303 & & 842 & 69 & & 3 & & 903 & 6006 & 1673 \\
\hline 11 & & & & 30 & & 876 & 7996 & & & & 907 & 8006 & 1423 \\
\hline 12 & & & & 30 & & 91 & 68 & & & & & & 1866 \\
\hline 13 & & & & 30 & & 910 & 7964 & & & & 911 & .8006 & 2039 \\
\hline 14 & & & & 300 & & 897 & & & & & 907 & & 2272 \\
\hline 15 & & & & 297 & & 884 & 2.0974 & & & & 904 & 2.1006 & 2536 \\
\hline 16 & & & & 29 & 865 & 871 & 1.7969 & & & 6910 & 90 & 1.8006 & 2608 \\
\hline 17 & & & & 29 & & 85 & 3998 & 24 & & 7510 & 89 & 1.4006 & 2475 \\
\hline 18 & & & & 28 & & 846 & & & & & 80 & .2006 & 2049 \\
\hline 19 & & & & 283 & & 833 & & & & & 891 & .0006 & 1742 \\
\hline 20 & & & & 279 & 0.9372 & 820 & 0.8960 & 17 & & 9410 & 888 & 0.9006 & 1710 \\
\hline 21 & & & & 276 & 0.9985 & 808 & 1.1976 & 1428 & & 1.0010 & 884 & 1.2006 & 1449 \\
\hline 22 & & & & 27 & & 79 & & & & & 881 & 2.2006 & 996 \\
\hline & & & 43 & 269 & & 78 & & 90 & & & 878 & 2.1006 & 843 \\
\hline 24 & 47.00 & 50.00 & 432 & 266 & 1.1972 & 770 & 2.0958 & 909 & 300 & 1.2010 & 875 & 2.1006 & 843 \\
\hline
\end{tabular}

Tabel 3. Kecepatan gelombang P pada beberapa medium (Bonner and Shock, 1981)

\begin{tabular}{lcc}
\hline \multicolumn{1}{c}{ Material } & Unsaturated & Water-saturated \\
\hline Sand & $200-1000$ & $900-2000$ \\
Sandy-gravel & $400-600$ & $900-1600$ \\
Clay & $700-1200$ & $1100-2500$ \\
Alluvium & $400-900$ & $1000-2000$ \\
Soil & $320-450$ & $1000-1800$ \\
Weathered bedrock & $300-900$ & $1200-1800$ \\
Granite & $4200-5500$ & $5000-6500$ \\
Basalt & $5500-6200$ & - \\
Sandstone & $2500-5100$ & $3000-5500$ \\
Limestone & $3300-6200$ & - \\
Methamorphic rock & $3000-6500$ & - \\
\hline
\end{tabular}

\section{Pemodelan Pergerakan Tanah}

Setelah diperoleh data hasil pengolahan dari pengukuran seismik refraksi, kemudian dilakukan rekonstruksi atau pemodelan tomografi 2 dimensi. Pemodelan ini dilakukan dengan membuat perangkat lunak tomografi dengan metode SIRT dan Gauss-Seidel. Konsep pemodelan dapat diilustrasikan secara dua dimensi seperti pada Gambar 6. Sumber dari permukaan searah sumbu $X$ dan penerima sumbu $\mathrm{Y}$. Distribusi kecepatan $\mathrm{v}(\mathrm{x}, \mathrm{y})$ atau perlambatan $f(x, y)=1 / v(x, y)$ pada profil ini dapat diperoleh dari inversi sesuai dengan waktu awal yang diterima oleh penerima (Qifeng Yin, dkk., 2014).

Metode SIRT merupakan sebuah algoritma yang berasal dari pengembangan metode Algebraic Reconstruction Technique (ART) yang digunakan untuk merekonstruksi citra 2D dari data proyeksi. Pada metode SIRT, proses iterasi dimulai dengan merekonstruksi semua elemen fi (Persamaan 4). Elemen fi ini 
menyatakan intensitas bahan di dalam sel ke j pada sinar ke $i$. Perbedaan masing-masing iterasi diperhitungkan antara data pengukuran dan hasil rekonstruksi sejumlah elemen sepanjang sinar ke $i$ yaitu $\sum_{i=1}^{N} f_{i j}$. Bila jalur rambatan gelombang seismik ' $\mathrm{i}$ ' dinyatakan dengan $\mathrm{Li}_{i}$ dan $\mathrm{T}_{\mathrm{i}}$ sebagai waktu tempuh (travel time), maka (Qifeng Yin, dkk., 2014) :

$\tau_{i}=\int_{L_{i}} \frac{d f}{v(x, y)}=\int_{L_{i}} f(x, y) d f$

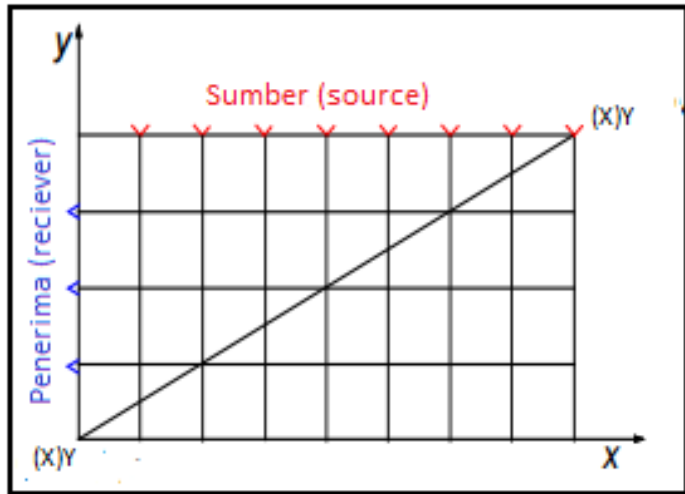

Gambar 6. Sketsa daerah rekonstruksi diskrit

Sedangkan Metode Gauss-Seidel digunakan untuk menyelesaikan sistem persamaan linear (SPL) berukuran besar dan proporsi koefisien nolnya besar, seperti sistem-sistem yang banyak ditemukan dalam persamaan diferensial. Metode iterasi Gauss-Seidel dikembangkan dari gagasan metode iterasi pada solusi persamaan tak linier. Metode eliminasi ini dilakukan untuk menyelesaikan suatu persamaan linier dengan mencari nilainilai variabel yang belum diketahui dengan menggunakan rumus iterasi (seperti pada Persamaan 5). Rumus iterasi untuk hampiran ke-k dengan nilai $\mathrm{i}=1,2, \ldots, \mathrm{n}$ dan $\mathrm{k}=1$, $2,3, \ldots$, adalah sebagai berikut (Qifeng Yin, dkk., 2014):

$x_{i}^{(k)}=\frac{1}{a_{i i}}\left(b_{i}-\sum_{j=1} a_{i j} x_{j}^{(k-1)}\right)$

Software dirancang berbasis visual basic dengan memasukkan fungsi numerik SIRT dan Gauss-Seidel dengan parameter perubahan dari kedudukan refraktor di setiap lapisan batuan hasil dari pemrosesan pengukuran seismic di lokasi penelitian. Dengan software ini kemudian dilakukan pemodelan data (data series) hasil pengolahan seismik pada lokasi yang sama, sehingga dapat diketahui seberapa besar kecepatan lapisan tanah atau batuan mangalami pergerakan. Hasil pemodelan dengan software tomografi dapat dilihat pada Gambar 7 dan 8 .

Pada Gambar 7 memperlihatkan salah satu model pergeseran lapisan batuan pada titik di geophone 8 yang menunjukkan angka persamaan $\mathrm{y}=0.567009+4.7404 \mathrm{E}^{-04} \mathrm{x}$ dalam satuan $10^{-2}$ meter untuk pergerakan $(\mathrm{Y})$ dan bulan (30 hari) untuk periode pengamatan (X). Berdasarkan pengolahan tomografi tersebut pada pengamatan di lokasi I, persamaan deformasi batuan terbesar adalah $y=1.7593$ + 3.077. $\mathrm{E}^{-03} \mathrm{x}$, dimana y adalah nilai perkiraan pergerakan batuan di masa datang dengan x sebagai input nilai bulan (30 hari). Sehingga dalam satu bulan (30 hari) nilai y $=$ $1.7593+3.077 \times 10^{-3} \times 30$ hari atau sebesar $1,85 \mathrm{~cm} / 30$ hari pengamatan. Sehingga untuk 1 hari sebesar $0.6 \mathrm{~mm} /$ hari $(0,06 \mathrm{~cm} /$ hari $)$, maka dalam 1 tahun mengalami deformasi sebesar $22 \mathrm{~cm}$. Pada Lokasi I besarnya deformasi batuan cukup signifikan, mengingat daerah pengamatan merupakan daerah bekas longsoran dan bagian atas pengamatan sudah menjadi daerah bukaan, dan diperkirakan masih mengalami pergerakan untuk menuju kondisi keseimbangan. Selain itu pengamatan juga dilakukan pada saat bulan dengan curah hujan lebih tinggi dibanding bulan-bulan sebelumnya.

Adapun pengolahan tomografi pada lokasi dua didapatkan persamaan deformasi batuan terbesar adalah $y=0.637+4.023 \mathrm{E}^{-03} \mathrm{x}$ sehingga nilai $y=0.637+4.023 \times 10^{-3} \times 30$ hari atau sebesar $0,76 \mathrm{~cm} / 30$ hari pengamatan. Karenanya, untuk 1 hari sebesar 0.25 $\mathrm{mm} /$ hari $(0.025 \mathrm{~cm} /$ hari). Deformasi lokasi II lebih rendah karena berupa lapangan datar di daerah pemukiman yang relatif stabil dan belum terjadi perubahan bentang alam. Meskipun pada lokasi I telah terjadi kerusakan yang cukup parah dengan kecepatan pergerakan sebesar $0.6 \mathrm{~mm} /$ hari, namun berdasarkan acuan "Standarisasi rekayasa penanganan keruntuhan lereng jalan pada tanah residual dan batuan, Pedoman Teknis, Puslitbang Jalan dan Jembatan (Pd T-09-2005-B), kondisi tersebut masih dikategorikan sebagai pergerakan lambat $(0.3 \mathrm{~m} / 5$ tahun - $1.5 \mathrm{~m} /$ tahun $)$ dengan pola gerakan berupa aliran. 


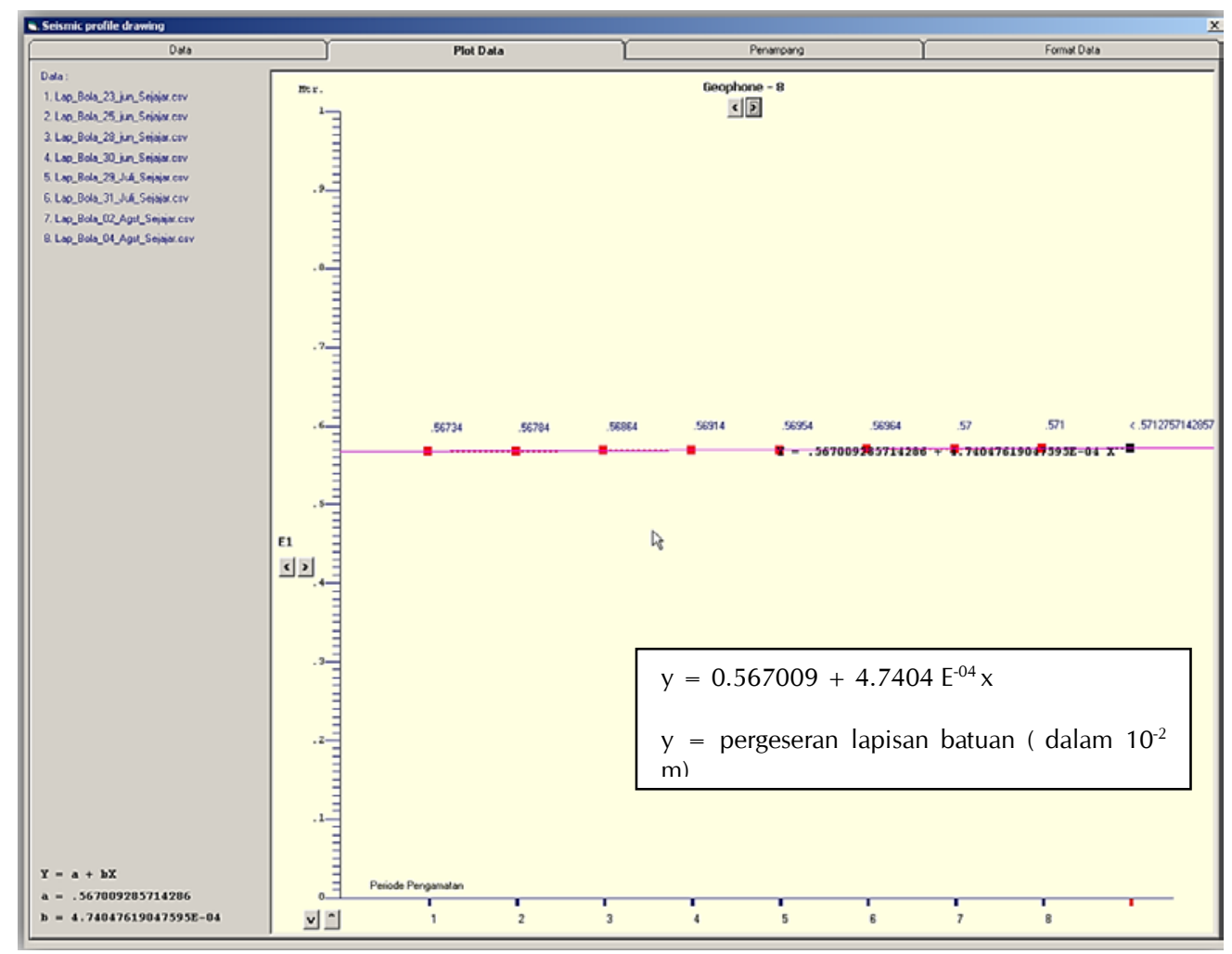

Gambar 7. Persamaan pergerakan batuan berdasarkan perhitungan software

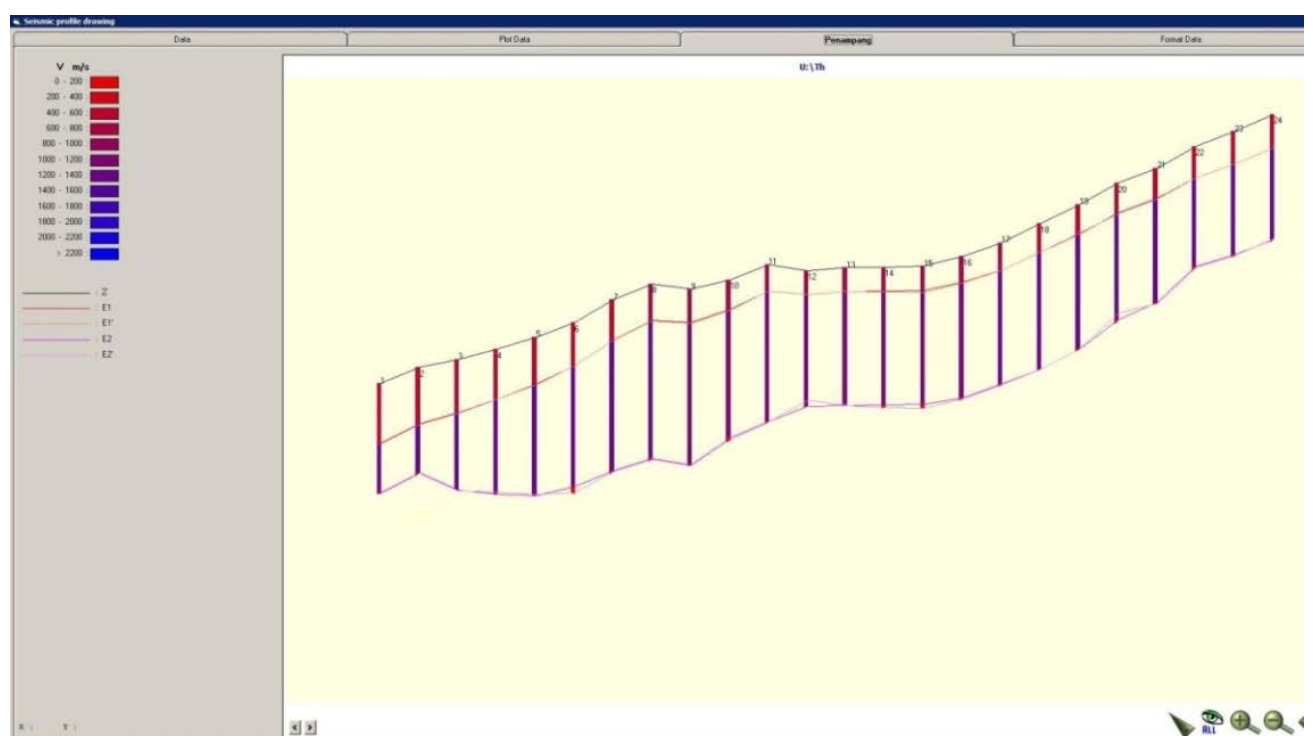

Gambar 8. Permodelan posisi lapisan batuan di lokasi 1 daerah penelitian 


\section{KESIMPULAN DAN SARAN}

\section{Kesimpulan}

- Jumlah lapisan batuan yang berhasil dideteksi oleh seismik refraksi yang memengaruhi kondisi ketidakstabilan dan pergerakan tanah pada penelitian ini adalah sebanyak 3 lapisan. Lapisan pertama mempunyai kecepatan gelombang $312-1100$ m/s diinterpretasikan sebagai lapisan top soil berupa tanah lapukan lempung pasiran dengan ketebalan bervariasi antara 1.24 $3.18 \mathrm{~m}$. Lapisan kedua mempunyai kecepatan gelombang 958 - $1827 \mathrm{~m} / \mathrm{s}$ diinterpretasi sebagai lapisan batulempung yang impermeable yang berperan sebagai bidang luncur longsoran dengan ketebalan bervariasi antara 2,57 - 7,50 m, dan lapisan ketiga mempunyai kecepatan gelombang 1143 - 2190 m/s diprediksi sebagai lapisan pasir.

- Dari data hasil penelitian lapangan, untuk kondisi batuan pada lokasi I, hampir tidak terjadi perubahan pada kecepatan rambat gelombang, sehingga dapat dikatakan pada lapisan ini kondisi batuan relatif stabil, meskipun ada beberapa titik yang mengalami perlambatan namun sangat kecil. Sedangkan pada lokasi II, dengan kondisi lereng relatif miring, menunjukkan perubahan kecepatan di beberapa titik pengamatan, namun perubahan kecepatan yang ekstrem tidak ditemukan.

- Hasil pengamatan lapangan dan pemodelan, dapat diprediksi bahwa terjadi deformasi batuan pada lokasi I (bidang miring) terbesar $0.6 \mathrm{~mm} /$ hari atau $21.9 \mathrm{~cm} /$ tahun, sehingga bila tidak dilakukan penanganan yang benar pada bagian atas, dikhawatirkan akan terjadi kelongsoran kembali. Sedangkan untuk kondisi lokasi II, relatif stabil dan dengan asumsi tidak terjadi perubahan bentang alam yang ekstrem pada sekitar lokasi tersebut, maka dapat disimpulkan tidak akan terjadi deformasi batuan yang menyebabkan kerusakan fatal.

\section{Saran}

Pemerintah Daerah maupun para pemuka masyarakat setempat perlu melakukan hal-hal sebagai berikut :
- Perlu menjaga bentang alam, terutama pada lokasi yang mempunyai kemiringan lereng tinggi dengan melakukan penataan pada bagian atas lereng, dan menghilangkan catchment area, dengan menyalurkan air ke saluran air yang ada.

- Melakukan studi regional untuk seluruh areal sekitar penambangan dan lokasi hunian penduduk, untuk mengurangi terjadinya bahaya yang lebih besar lagi.

\section{UCAPAN TERIMA KASIH}

Ucapan terima kasih penulis sampaikan kepada Bapak General Manager UPE Ombilin beserta staf yang telah membantu mencarikan lokasi yang tepat untuk penelitian ini. Terima kasih juga disampaikan kepada Bapak Supardino sebagai programmer yang telah membuatkan perangkat lunak untuk mengolah data hasil pengukuran lapangan serta rekanrekan yang telah membantu penelitian ini hingga selesai.

\section{DAFTAR PUSTAKA}

Aydan, Omer, Kumsar, Halil, 2009. An experimental and theoretical approach on the modeling of sliding response of rock wedges under dynamic loading, Rock Mechanic Rock Engineering, DOI 10.1007/s00603-009-0043.

Bonner, B. P. and Schock, R. N. 1981. Seismic wave velocity, in Physical properties of rocks, Y. S. Touloukian, et al., Eds., McGraw Hill.

Dennis, N. D., Ooi, C. W. and Wong, V. H., 2006. Estimating movement of shallow slope failures using time domain reflectometry, Proceeding TDR 2006, Purdue University, West Lafayette, USA.

Ferrero, A.M., Migliazza, M., Tebaldi, G., 2010. Development of a new experimental apparatus for the study of the mechanical behaviour of rock discontinuity under monotonic and cyclic loads, Rock Mechanic, Rock Engineering, hal. 685-695.

Gorsevski, P.V, Gessler, P.E, Foltz, R.B, Elliot, W.J, 2006. Spatial prediction of landslide hazard using logistic regression and ROC, 
Transactions in GIS, 10(3): 395-415, Blackwell Publishing Ltd.

Henryk, M., Zenon, P., Elzbieta, P., Jerzy, K., 2003. Prediction of slope failure using seismic refraction and modelling, University of Mining and Metallurgy and Polish Academy of Sciences, Poland.

Hoek, E., Carranza, T. C. and Corkum, B., 2002. Hoek Brown failure criterion - 2002 edition, Proc. 5th. North American Rock Mechanics Symposium and 17th Tunneling Association of Canada Conference. ATM TAC 2002. University of Toronto, University of Toronto, pp. 267271.

lyer H.M., and Hirahara K., 1993. Seismic tomography: Theory and practice. New York: Chapman \& Hall.

Karnawati, D., 2005. Bencana alam gerakan massa tanah di Indonesia dan upaya penanggulangannya, Jurusan Teknik Geologi Fakultas Teknik Geologi Universitas Gadjah Mada, Yogyakarta.

Koning, T., 1985. Petroleum geology of the Ombilin Intermonate Basin, West Sumatera, Proceedings Indonesian Petroleum Association 5th Annual Convetion.

Kusumosubroto, H., 2013. Aliran debris dan lahar, pembentukan, pengaliran dan pengendaliannya. Graha Ilmu, Yogyakarta.

Lateha, H, Jefriza, M.W.M, Taiba, B, Khan, Y.A, 2010. Monitoring of hill-slope movement due to rainfall at Gunung Pass of Cameron Highland District of Peninsular Malaysia, International Journal of Earth Sciences and Engineering, ISSN 0974-5904, Vol. 03, No. 01.

Li, J., Ma, G., Xing, H., 2009. Analysis of wave propagation through a filled rock joint, Rock Mechanic Rock Engineering, DOI 10.1007/s 00603-009-003-5.

Narwold, C.F and Owen, W.P, 2003. Seismic refraction analysis of landslide, Geophysics and Geology Branch California Department of Transportation Sacramento, CA 95864.

Ohta, Y., Aydan, O, 2009. The Dynamic responses of geo-Materials during fracturing and slippage, Rock Mechanic Rock Engineering, DOI 10.1007/s00603-0100095-4.

Pedoman Teknis No. Pd T-09-2005-B, 2005. Standarisasi rekayasa penanganan keruntuhan lereng jalan pada tanah residual dan batuan, Puslitbang Jalan dan Jembatan.

Qifeng Yin, Dongming Pan, Jingcun Yu, 2014. Application of well-ground seismic computerized tomography technology in underground structure detection, EJGE, Vol. 19.

Sato, T., T. Kikuchi, dan K. Sugihara, 2000. In situ experiments on an excavation disturbed zone induced by mechanical excavation in Neogene sedimentary rock at Tono mine, central Japan. Engineering Geology, hal. 97108.

Tofani, V, Segoni, S, Agostini, A, Catani, F and Casagli, N, 2013. Technical note: Use of remote sensing for landslide studies in Europe, Department of Earth Sciences, University of Firenze, Florence, Italy.

Watanabe T., and Sassa K., 1996. Seismic attenuation tomography and its application to rock mass evaluation. International Journal Rock Mechanics and Mining Sciences 33:467-77.

Wieczorek, G.F., and Snyder, J.B., 2009. Monitoring slope movements, in Young, R., and Norby, L., Geological Monitoring: Boulder, Colorado, Geological Society of America, p. 245-271, doi: 10.1130/2009.

Zulfahmi, Astika, H, Mujahidin, S, 2009. Pengembangan sistem dan alat pemantauan sederhana untuk mendeteksi keruntuhan batuan atap (roof failure) pada tambang bawah tanah, Kolokium Pertambangan 2009, Puslitbang Teknologi Mineral dan Batubara - tekMIRA, Bandung. 